\title{
ANS Notes
}

\section{MEMBERSHIP COMMITTEE OF THE}

\section{AMERICAN NAME SOGIETY 1961-1962}

In response to an inquiry by the Chairman, dated October 5, 1961, the following persons signified their willingness to join the Membership Committee of $A N S$ or to continue to serve on it:

Samuel H. Abramson, White Plains, New York

Cortland P. Auser, Dept. of English, Air Force Academy, Col.

Arthur Berliner, New York, N.Y.

F. W. Bradley, Columbia, South Carolina

William Childers, English Department, University of Florida, Gainesville, Florida

Geart Droege, Chicago, Illinois

A. R. Dunlap, Dept. of English, University of Del., Newark, Del.

J. C. Furnas, Lebanon, New Jersey

Elsie Mag, G. \& C. Merriam Company, Springfield, Mass.

T. M. Pearce, University of New Mexico, Albuquerque, N. M.

P. Burwell Rogers, English Department, Bucknell University, Lewisburg, Pennsylvania

Stowell Rounds, Cannondale, Connecticut

J. B. Rudnyćkyj, Department of Slavic Studies, University of Manitoba, Winnipeg, Canada

Arthur C. Schofield, Peoples Broadcasting Corp., Columbus, Ohio Elsdon C. Smith, Evanston, Illinois

James Alexander Thorburn, Department of English, Texas

Western College of the University of Texas, El Paso, Texas

Gutierre Tibón, Bucareli 48, Ciudad de México, México

Frank H. Trolle-Steenstrup, Washington, D.C.

Charles L. Wrenn, Pembroke College, Oxford, England.

Some who had served on the Committee replied negatively. It is assumed that those who did not respond no longer wish to be on the Committee.

Any member who did not receive the inquiry or overlooked replying and who wishes to work on the Committee is asked to communicate with the Chairman. 
Addendum to Membership Committee:

Julius L. Rothman, The City College, New York

\section{THE NAME OF EASTER ISLAND}

In my article on Indian Place Names in South America and the Antilles (Names, vols. 8 and 9), I made reference to the ancient Polynesian name of Easter Island, viz., Te Pito o te Henua 'the umbilicus of the earth' (vol. 8, No. 4, p. 205). This designation is usually interpreted as the 'center of the earth'; so, for instance, Father Sebastian Englert in La tierra de Hotu Matu'a (Padre Las Casas, 1948), p. 485. The reason why this name was given to the island is explained by Father Englert as follows (in translation): "... that the first refugees who arrived from that part of Hiva (i.e., the name of the sunken continent from where the Easter Islanders were supposed to have come according to native tradition; cf. op.cit., p. 440) - probably the central part - which was called Te Pito o te Henua, gave this name to the island in remembrance of their country which had disappeared in the catastrophe" (op.cit., pp. 19-20). This explanation by Father Englert gives at hand that he himself did not consider such a name in itself very appropriate for one of the remotest islands in the Pacific.

The question is, however, whether the interpretation 'the center of the earth' is at all tenable. In the related and far better known Polynesian language of the Maoris, te pito o te whenua rather means the very opposite: in Herbert W. Williams' A Dictionary of the Maori Language (6th edition, 1957), the word pito is rendered (beside the original sense, for which see above) by 'end, extremity.' As a matter of fact, the well-known passage in Matthew 12:42, "for she came from the ends of the earth (to hear the wisdom of Solomon)," is translated as follows in the Maori Testament (British and Foreign Bible Society. London, 1894): i haere mai hoki ia $i$ nga pito o te whenua.... On the strength of this evidence, I would suggest this to be the meaning of the name of Easter Island as well.

Linguistic Seminar, University, Lund

Nils M. Holmer 


\section{IT SOUNDED JUST AS THOUGH YOU SAID, "PLONIA HOOGENBOOZEM"}

If your surname were Introlligator, Turnipseed, Bedworthy or Canary, you might hope to minimize it by christening your children John or Mary. Bolder spirits, however, rejoice in odd last names and cap them with even odder first names. This is how name collectors are born - amateur name collectors, as opposed to onomatologists.

As an amateur I love to think that there are people in the world called Baisley Elebash, Captara Lavender, Quay Clush and Breading Furst.

I've always enjoyed reading about those public figures who can never be confused with anyone else: such notables as Oveta Culp Hobby, Sosthenes Behn, Almerindo Portfolio, F. Skiddy Von Stade and Hyacinth Ringrose.

I am grateful for that covey of British knights: Piers Legh, Flinders Petrie, Nutcombe Hume and Cloudsley Shovel (whose parents probably never heard "Keep a-pushin' and a-shovin' and a-pushin' and a-shovin' Till you push them clouds away").

I am glad that I learned early in my filmgoing to read the credits. My life would have been the poorer without Hermes Pan, Finis Farr, Van Nest Polglase, Red Law, O. O. Dull, Nova Pilbeam, Wyrley Byrch, Eily Malyon and Ub Iwerks.

I love names that evoke a mental image, such as Tudor Cork, Joy Kwaack, Mars Vasting, Primrose Stale, Mint Mays, Faith Ponder, Charlemagne Tower, Rosebud Custard, Pixie Pease, Gay Gamble, Loye Lark, Hoppin Poole, Pallie Pidgeon, Arden Constant, Fountain Meadows and Liberty Dick. I am also devoted to Gay Juliana, most of whose mail, naturally, is addressed to Juliana Gay; to Daisy League, obviously the feminine counterpart of Ivy League; and to Bernon Woodle (did he ever get to Dunsinane?).

I am glad to have known Ah Burnetty but not well enough to call her by her first name. I am also glad that others, not I, asked $A . V$. Carlton and $C$. O. Steele what their initials stand for: Americus Vespucci and Columbus Ohio.

I am happy to know about Doctor Slaughter, Captain Major, Judge Laws, Nurse Diet and Father Archdeacon. It seems fitting, too, that Abel Just should have become a lawyer, Mischa Violin, a musician, and Champness Keep, a jailer.

Some people I'd like to bring together, such as Penna Tew and Lyn Few, or Spring Byington and Winter Hall. How would Peregrine Wroth react to Delight Butts, Ima Beam, Merry Hink or Gaylord Joy? - Ruford Monk to Nina Nunnery? Heather Angel to Fairlie Nicodemus? - Prince Littler to Verneze Queen?

Marriage has wrought some astonishing combinations, as when a girl named Mountain married a man named Pond, a Cotton added a Sheets, a Hard married a Wear and Miss Hurtt married Mr. Silence.

Mischance brought a rare cluster into a New York Times story of a shooting affray some years ago. Beaufort Swancutt, a soldier, murdered Lourdine Livermore and wounded Aldace Minard. Prompt arrivals on the scene included Earle Sarles, the men's commanding officer, and the local police chief, Nestor Brule. Swancutt was apprehended while scuffling with a bystander named Euel Atchley. 
The innocent joys of a name collector are boundless. One never knows when luck will strike. Asking a new acquaintance her name, my collection was enriched by Tisby Choice. Seeking a prosaic telephone number, I found Minor Bond in the directory. Office mail has brought letters signed by Dilliana Gizman, Moycah Koree and Ora Tyree. One can look forward to reading in the newspapers about Outerbridge Horsey and Spruille Braden or to stories bylined Epsie Kinard and Denise McCluggage. (Lately I seem to have lost track of Ordway Tead, Marriner Eccles and Hype Igoe.)

No one is more aware than I of my frivolous approach to nomenclature. After all, what is the point of just sitting around thinking about someone named Plonia Hoogenboozem ? Discussing this recently with a friend, I said that I should have become an onomatologist, that if I were properly serious-minded I could have taken a master's degree with a thesis on Boopsie Winblad. "Boopsie Winblad?" he repeated with an equal want of sobriety. "Oh, that must be the tunnel in the fun house at Coney Island."

Montclair, N.J.

Marjorie O'Shaughnessy

\section{Editor's Page}

On behalf of the American Name Society we would like to express our gratitude to Fairleigh Dickinson University (FDU) for the substantial five-year subsidy granted the $A N S$. Thesse additional funds will be applied toward publication of the journal and other projects such as the monograph series we are initiating. Anyone wishing to submit a lengthy work on names should communicate with any member of the ANS Monograph Committee which consists of Professors E. Wallace McMullen, Chairman; Kemp Malone; T. M. Pearce; and J. B. Rudnyćkyj.

FDU has also provided the Editor with two student grants-in-aid - the Misses Remé Grefalda, who helps proofread, and Valerie Forgione, who performs various mechanical duties connected with the Editorial office.

In assuming the responsibilities of this office the Editor wishes to express his indebtedness to the previous Editors, namely, Professors Gudde, Beeler and Georgacas, for to a great extent they formulated and maintained the basic policies adopted and fostered by the Society. It is our earnest hope to preserve and thus to strengthen this tradition. We are primarily interested, therefore, in receiving onomastic contributions of sound workmanship and solid content. 